\title{
Crisis and Complementarities: A Comparative Political Economy of Economic Policies after COVID-19
}

\author{
Bob Hancké, Toon Van Overbeke and Dustin Voss
}

\begin{abstract}
We examine economic policy responses to the COVID-19 induced economic collapse in Germany (a coordinated market economy) and the UK (a liberal market economy). The two countries responded to the symmetric economic shock with very similar furlough and business credit schemes to stabilize the demand and supply sides of the economy. However, since these policies fed into very different political-economic structures in both countries, they produced very different results. We attribute this divergence to the effect of "institutional complementarities," the notion in Varieties of Capitalism that different elements of a system are mutually articulated and, therefore, mutually reinforcing beyond their initial contribution, or vice versa. Our results serve as a cautionary tale to policymakers that introducing policy elements developed in other institutional contexts is complex and challenge us to consider systematically the way in which institutional frameworks actively shape policy outcomes.
\end{abstract}

$T$ he COVID-19 health crisis has hit the advanced capitalist world hard. In early 2020, only weeks after the first cases were detected in Europe, many workplaces closed, especially in the manufacturing sector. While many employees in the clerical service sectors were able to work at least part of the time from home, that was impossible in manufacturing, where the physical presence of both labor and capital are crucial for production. Global and regional supply chains ground to a halt, factories were mothballed, workers furloughed, and sales points significantly reduced.

The COVID-19 crisis is a tragic but revealing natural experiment that allows us to examine how similar economic policies affect different countries. All advanced

\section{Bob Hancké (1) is Associate Professor of Political Economy at the London School of Economics and Political Science (r.hancke@lse.ac.uk).}

Toon Van Overbeke (1) is a Doctoral Candidate in Political Economy at the London School of Economics and Political Science (t.t.van-overbeke@lse.ac.uk). His research focuses on the comparative political economy of automation and its electoral outcomes in Europe.

Dustin Voss (1) is a Doctoral Candidate in Political Economy at the European Institute of the London School of Economics and Political Science (d.j.voss@lse.ac.uk). He researches the political determinants of institutional change in European financial systems. capitalist nations were hit in very similar ways, all shut down their economies despite the obvious costs, furlough schemes supported workers' incomes everywhere, and businesses were closed and kept on life support through cheap credit and grants, even in the market-dominated Anglo-Saxon economies. Especially in the latter, the contrast with the support schemes in the wake of the financial crisis only a decade earlier is stark: after 2008 these more liberal economies did not introduce subsidies, business grants, and furlough schemes and, with the exception of banks and very large companies-both considered systemically important-did not interfere in markets on anything like the scale we have seen in 2020. COVID-19 became the great equalizer, in other words: all countries addressed the very similar economic fallout of the pandemic through very similar economic policies.

We argue that there is a nasty sting in the tail of this story. This paper examines responses to the economic effects of COVID-19 in Germany, a paradigmatic case of the "Coordinated Market Economy" (CME) in the Varieties of Capitalism framework (Hall and Soskice 2001), where strategic links between business, labor, banks, and government offer the organizational matrix for economic coordination, and the UK, a "Liberal Market Economy" (LME), where markets and contracts are the dominant mode of economic organization. Given the magnitude of the symmetric shock and the similarity of the substance and timing of policy responses in these two countries, but emblematic of the advanced capitalist world as a whole, we would a priori expect similar, or at least convergent, effects 
in terms of how household incomes were stabilized and businesses shielded. But that is not what happened. In Germany, the wage subsidies ended up preserving skills alongside jobs and the business loan and grant schemes secured the survival of the medium-sized manufacturing and service firms at the heart of the country's economic success. In the UK, in contrast, many low-skilled jobs received repeated short-term subsidies, while very small businesses in the service sectors were the primary beneficiaries of financial support.

While no two countries are ever exactly the same, the initial convergence in terms of shocks, active responses and their timing would have predicted broadly similar outcomes as well. The initial responses to the pandemic by some governments and the disparities in health and economic performance (Vlandas 2020) do not help us much in understanding this variation. By examining precisely those economic policies that were the same everywhere (Sandbu 2021), including in Germany and Britain, we pre-empt that argument: The active intervention by governments, often against their own ideological predilections and contradicting the policies adopted during the 2008 financial crisis, or against their "model" of capitalism, to stabilize labor markets, employment, and wages, and the cash injections for businesses that were stopped from trading.

By examining areas where strong governments with an almost unlimited fiscal and political mandate adopted what everyone considered the gold standard responses to the crisis, we also avoid an analysis in which governments are simple passive extensions of production regimes (Wood 2001; Howell 2003). In fact, in both countries, the policies actually ran against the prevailing macro- or microeconomic consensus: Germany normally abhors deficits and activist fiscal policy, while ever since the Thatcher era, the UK prefers market forces to sort out an economic crisis. If the recent experience of the financial crisis is a guide, we would have expected (more) bankruptcies and (higher) mass unemployment in the UK, especially with a right-wing Conservative government in office, not wage and business support schemes. And German fiscal prudence would have suggested a more measured approach to the economic fallout of the pandemic. Despite all this activism, however, the economic policies unfolded along very different lines, following the logic of the two distinct underlying capitalist models.

We limit this paper to the first COVID-19 wave lasting from March until August 2020 for two main reasons. The first is methodological: Limiting our analysis to the first wave constitutes the "purest" comparison. By the time of the "second" wave in the fall of 2020, governments were not any longer just responding to COVID-19 infections but also to the second-order effects of the policies they adopted in the first wave. In addition, going beyond the first wave would make us chase a moving target, which conflates economic policies and their effects in immediate response to the pandemic with the interaction of these policies with underlying independent political-economic processes and conditions. This is especially important in the case of the UK, where the response to the first wave in early spring 2020 was at worst only marginally affected by the politics and economics of the looming departure from the EU-something that was certainly no longer the case in November and December 2020, when the government was responding to the second wave (Sampson 2020). The divergent outcomes that we analyze in this paper are, therefore, as much as they can be isolated, the outcome of responses to COVID-19, and not confounded by other processes.

We argue here that the outcomes in Germany and the UK were so different because of the articulation of the policies with the existing institutional frameworks in labor and financial markets. We build this argument on an essential though sometimes underplayed theoretical point in the Varieties of Capitalism $\left(\mathrm{VoC}_{\mathrm{O}}\right)$ framework at the basis of our comparative analysis: the notion of institutional complementarities (Hall and Soskice 2001, 17-21). Translated in terms of the cases here, the effectiveness of the policies was a result of the degree to which they tapped into the institutional resources that the underlying production regimes offered. Local savings banks, for example, with close long-term relations with local companies were particularly well positioned to dispense funds quickly to businesses that faced problems in Germany. Their absence in the UK meant that large banks handled credit requests from companies they did not know very well or at all. The pre-existing structure of the industrial credit system actively shaped the way the almost exact same financial support instruments played out in practice.

The divergence was, therefore, not primarily due to different initial positions in COVID-related health (it was far from clear in February 2020 which country would be hit hardest). Nor was it the result of government incompetence: Fundamentally similar policies were adopted by two administrations that enjoy a reputation of administrative competence. And the differences in industrial structure between the UK and Germany do not explain much of the variation either: The need for distancing made German manufacturing as much a sitting duck as London's coffee shops; In fact, much of the service sector in the UK stayed in business because of widespread workfrom-home arrangements, while manufacturing closed down in many places.

The balance of this paper is organized as follows. We begin with a short theoretical review that introduces our argument regarding institutional complementarities in more detail. We then present case material for the UK and Germany, which relies on a combination of public and official statistics, interviews, and press material. We first 
focus on labor market policies since they offered the template for the economic support measures adopted in other areas. A final section, then, brings out the important comparison between German and UK business support schemes and financial market institutions in order to conclude with reflections on complementarities, policy articulation, and institutional adjustment.

\section{Policies and Institutions: The Role of Complementarities}

COVID-19 was a massive symmetric shock that produced vast uncertainty. As a result of the extremely contagious nature of the virus and its lack of immediate detection, "social" distancing was introduced everywhere leading to the closure of practically all organizations that require a physical presence for the good or service to be producedmuch of the public sector, hairdressers, restaurants, schools, and manufacturing. Industrial work could only be performed more or less as normal if considered essential, while many worked from home or were furloughed, keeping their job while paid a replacement income. Manufacturing output fell sharply, local or regional supply chains dried up, and since the epidemic had reached global proportions very quickly, global supply chains collapsed. The world, especially the OECD countries at first, experienced a historic fall in economic activity as a result of a simultaneous supply and demand shock.

The initial symmetric shock of the pandemic elicited symmetric economic policy responses everywhere: macroeconomic "stimulus" by central banks and finance ministries, wage subsidies and furlough schemes to prop up household incomes and prevent unemployment, and grants or cheap loans to keep businesses afloat. The ECB, the Federal Reserve, and the central banks of Japan and the UK embarked on quantitative easing activities on a scale that dwarfed the bailout packages the financial sector had received a decade earlier (Cavallino and De Fiore 2020). Finance ministries, in turn, even those that up until recently had ignored the negative real interest rates on government debt and insisted on consolidating their fiscal position or imposed austerity, suddenly rediscovered the Keynesian virtue of countercyclical spending.

Germany, Austria, Denmark, Belgium, and the Netherlands, some of the coordinated market economies, introduced wage subsidy schemes at a massive scale, as did France, Italy, and Spain. Most surprisingly, perhaps, in March 2020, barely a few weeks after the first cases emerged in the UK, the Johnson government also decided to hand out massive wage subsidies, and even the Trump administration in the United States installed a furlough scheme-in both cases for a limited time, but soon extended when it became obvious that the pandemic was not a short-lived crisis. Business grants became the norm everywhere despite their obvious anti-competitive nature; and state aid schemes for large companies in sectors such as air transport and automotive were introduced, often explicitly ignoring WTO fair trade rules or EU competition policy (Economist 2020).

However, only a few months later, after what was considered the end of the first wave in the summer of 2020, the landscape of economic policies in the different countries displayed remarkable variation. The UK had stopped and started its furlough once and went on to do so twice more by early 2021, with fluctuating degrees of generosity. The German wage replacement scheme was extended for eighteen months in April 2020, after only a few weeks into the first wave, thus alleviating the burden on business and the uncertainty of households. Credit schemes targeted very large and very small firms in the UK, precisely those firms that the German business support schemes neglected. From a very similar starting point, and with essentially identical policy instruments, both countries ended up in a very different place.

Policy failure, including poor policy design, is the obvious explanation for these differences: Governments simply made poor choices, both in the policies they adopted and their implementation. While there is certainly an element of that at work here, this argument runs up against some important limitations, not least because the economic responses of both countries were almost exact copies of each other at almost the exact same time, as we described in our setup. In addition, there are also some important theoretical objections. First of all, epistemologically the case for policy failures is hard to make. How would we recognize failure other than ex post, i.e., when the policy has failed? That makes the argument impossible to falsify: By inadvertently selecting on the dependent variable, we can no longer assess if the policy was simply a bad idea or if the same policy may have worked under different conditions. Moreover, the policy-failure argument also presupposes the possibility of a benchmark "optimally designed" policy—a weak(er) administrative version of how neo-classical economics assumes contextfree economic optimality. But context is crucial in policy. Take the example of how car-safety regulations fail women: Because they were designed with only men (i.e., "male" crash test dummies) in mind, the differences in height, weight, and general body shape have cost many women life and limbs (Muller 2019; Criado-Perez 2019). This was not a poorly designed policy (it prevented severe injuries for most men) but ignored a crucial context of its implementation: Many women also drive cars, a rather basic social fact ignored by both engineers and policymakers.

With neither incompetence nor policy failure as persuasive sufficient explanations, the key alternative position in the debate would then ask if and especially how institutional frameworks that provide a relevant context for economic policies would matter. Traditionally, the approach in this area has been one in which institutions 
are "passive" refractors: an external shock to a system is, as it were, translated through the prevailing institutions, and that leads to an outcome that is different from what happens in places with other institutions (Steinmo, Thelen and Longstreth 1992, 1-31). While this helps understand many outcomes, the problem is that the causality is underspecified in this version of institutionalism: Which elements, actors, and actions play a critical driving role in that process?

More attention to institutional interactions, and their power in shaping outcomes, helps overcome this causality problem to some extent. The interactions between different elements in the relevant institutional framework produce new, emergent settings, which cannot be reduced to the constitutive elements in the link between institutions and policies. This conception of institutional frameworks is known as the theory of "institutional complementarities" (Hall and Soskice 2001; Milgrom and Roberts 1992). The interaction of two (or more) mutually reinforcing elements of a particular capitalist system can produce performance effects that are superior to the sum of the performance effects of each of these elements individually, and vice versa, sensible policies may fail in the absence of elements in the institutional make-up that reinforce their effects. The upshot is that cherrypicking economic policies does not work in the absence of underlying institutional elements that support them. In this particular case, very similar furlough and business grant schemes have fed into different systemic structures in the UK and Germany, which produced these diverging results.

The next section presents detailed empirical material to support this argument. We begin with the wage subsidy schemes that set the tone for most other support programs, and then pivot to the business loan and grant schemes. Starting from the obvious similarities, we will, when unpacking their actual operation, slowly edge toward a view of fundamentally different effects because of how these schemes were articulated with the existing institutional settings in labor markets and systems of corporate financing.

\section{Tales of the Unexpected}

On March 11, 2020, the World Health Organization declared COVID-19 a pandemic - a dangerous disease that rapidly crossed national borders, engulfed entire continents, and required dramatic responses, including strict population confinement. Two weeks later, governments in practically all OECD economies (with the exception of the United States) had imposed measures to curtail the spread of the virus. Because of the particular nature of the disease, infection was difficult to detect, often not until it was too late. Fighting contagion thus implied a complete preventative lockdown of close to entire societies and economies. In a few months' time,
GDP fell $10 \%-15 \%$ on an annualized basis in most advanced capitalist economies.

The precise transition from the acknowledgement of the problem to this all-out crisis management followed similar timelines in Germany and the UK. Both countries registered their first cases during the last week of January 2020 with many of the early cases tracing back to hard-hit Northern Italy. Both the British and the German governments initially remained cautious in their approach to the spread of the disease. The German health minister, Jens Spahn, and his UK counterpart, Matt Hancock, at the time both claimed that the chance of the virus spreading further was "very low," announcing only a few advisory measures (Die Rheinlandpfalz 2020; Reuters 2020). As the number of confirmed cases hit triple digits in both countries over the following weeks, they were forced into stronger action. The first concrete steps were taken by German local government. On February 24, 2020, an international trade fair in Frankfurt was cancelled, followed swiftly by the closure of schools and public buildings in the town of Heinsberg (North Rhine-Westphalia) on 26 February. Only a few days later the British government also unfolded its first COVID-19 action plan outlining possible measures in the event of further spread (Department of Health \& Social Care 2020). Theory, however, soon became reality for both countries as on March 8, 2020, the German government advised to cancel large-scale events, followed by the closure of schools, bars, and restaurants in most Länder and the closure of the border by late March 2020. The UK followed suit, announcing a nation-wide closure of public venues such as restaurants, pubs and gyms on 20 March 2020. Both countries would stay in lockdown until May of that year when restrictions of the first wave were slowly lifted. This unprecedented constraint on social life came at an enormous economic cost. In response, the British Treasury rolled out a $£ 330$ billion ( $\$ 440$ billion) fiscal stimulus on March 17, 2020, three days before the national lockdown. A similar plan was devised in Germany where the government officially suspended its legally enshrined debt brake in order to roll out its aid package on March 23, 2020.

In what follows we examine the economic policy responses in Germany and the UK to this unprecedented social shock during the "first wave", which lasted from mid-February to late August 2020. The selection of cases is important for our argument. Germany is a prototype Coordinated Market Economy (CME) in the Varieties of Capitalism framework (Hall and Soskice 2001), in which strategic (non-market) coordination between businesses, banks, and labor prevails. The UK, in contrast, is a Liberal Market Economy (LME), which relies primarily on markets and contracts as the main economic coordination mechanisms. Our hypothesis is that in these two countries, policies that are essentially the same in all relevant respects will lead to different modes of implementation 
that reflect these differences in economic coordination and do so with substantially different outcomes as a result. We attribute this divergence to the institutional frameworks that govern labor and financial markets and show that this interaction between policies and institutions was guided by their mutual articulation, i.e., the institutional complementarities that tie elements in the framework together into powerful constraints and opportunities. The test of our argument is simple, therefore: If the results of essentially identical policies are very similar in both countries, institutional variation in the advanced capitalist world would matter little; if they are different, however, and if we can link those differences to structural, systemic elements in the domestic economy, these differences in terms of institutional frameworks are critical for the way these policies operate.

\section{Labor Market Policies in the UK and Germany}

In response to the symmetric shock of COVID-19, workplaces in both economies quickly shut down, depriving employees of wages and households of income. Governments in both countries responded by offering wage subsidies to businesses so that wages were stabilized even if the company was temporarily unable to trade. However, as we will demonstrate, in their actual implementation these policies differed significantly, and their effects therefore diverged as well. In the UK, the initial wage subsidy scheme was generous but ultimately short-lived, and as a result many companies planned mass layoffs in the autumn of 2020. While they stabilized household income to some extent, they had relatively few effects beyond (the admittedly very important goals of) keeping unemployment low and stabilizing consumption in the comatose COVID economies. In Germany, the labor market policies were based on the existing "short-time work" (Kurzarbeit) scheme that allowed for part-time employment. There, the job retention scheme interacted with another institutional feature of Germany's political economy, namely strong unions, enticing employers to think of ways to hone and retain skills. As a result of these institutional complementarities, these policies not only stabilized shortterm employment and household income, but also supported the development of the skills basis of the German economy, safeguarding long-term job security along the way.

Both schemes looked very similar at the outset. In the UK, if a company shut down or saw its business significantly reduced as a result of the COVID shock, government subsidies would pick up $80 \%$ of the gross wage, capped at $£ 2,500$ (about $\$ 3,300$ ) as part of the Job Retention Scheme, the official name of the program. Applying to the scheme was relatively simple and unbureaucratic. In the UK, the company paid the worker who was not working and asked the government to refund $80 \%$ of that salary. Similarly, in Germany the standard was that up to $60 \%$ of the salary was paid, gradually increasing to $80 \%$ over time to reflect social criteria. Neither country required detailed documentation of financial problems. ${ }^{1}$ For its furlough scheme, Germany relied on the Kurzarbeit model developed in response to the 2008-2009 financial crisis, which allowed for partial wage subsidies if a company retained its workforce in part-time employment. In the UK, in contrast, the subsidy followed an "all or nothing" principle requiring furloughed workers to stay home altogether without the possibility of flexible working arrangements (i.e., at least until July 1, 2020, when flexible wage subsidies were introduced, but only for companies already in the scheme). Unsurprisingly, these schemes had the support of business organizations and trade unions in both countries (see Coulter 2020 for the UK) and even the opposition (on the left in the UK and on the right in Germany) agreed that the schemes were necessary for at least the immediate future.

Relatively small differences between the schemes and the labor markets, often deeply embedded in the institutionalized employment systems of both countries, mattered significantly for their implementation and effects, however. The German Kurzarbeit scheme is more than just a temporary arrangement to avoid unemployment. Employers are supposed to keep their workers on the books after the wage subsidy scheme runs out. In fact, very early on, Kurzarbeit was extended until late 2021 on existing terms to make that outcome a quasi-certainty. UK employers are under no such obligation: The scheme was (and is) —as its name suggests—a job retention scheme but nothing else. Finance Minister ("Chancellor") Sunak explained ending the scheme in October 2020 by stating that it might create false hopes of stable jobs. ${ }^{2}$

Furthermore, because of the strict (some would say "rigid") working time arrangements in Germany (Locke and Thelen 1995), which are carefully monitored by employee representatives, it was relatively easy to calculate part-time employment. As a result, the part-time wage subsidies under Kurzarbeit were a transparent and collectively policed possibility. The flexible working time arrangements in the UK, on the other hand, which are negotiated between individual employees and their employer, particularly outside the regulated public sector, made such a calculation of working time percentage very difficult. In other words, the existence of works councils and unions who manage working time rearrangements in Germany, and its absence in the UK, increased flexibility in the furlough scheme in the former-an instance of the institutional complementarities at the heart of our analysis here.

Implementation of furlough schemes. By mid-summer 2020, when the British scheme in its initial form had ended, about 9.6 million workers were furloughed, spread over 1.16 million companies or $61 \%$ of eligible employers. 
The hospitality sector registered the highest furlough rate of $77 \%$, while the retail sector furloughed the highest number of workers (all data from the official website of the fiscal agency; HMRC 2020). The German numbers are comparable. Half of all companies in the country had applied for wage support covering about 10 million workers or roughly $25 \%$ of the workforce. In some industries, such as hospitality, automobiles, and aviation, over $90 \%$ of employees found themselves in Kurzarbeit schemes (Martin 2020).

The two labor markets were not the same, of course, even before we examine the effects of regulatory and institutional frameworks. Self-employment is considerably higher in Britain, for example, estimated at $17.9 \%$ of the workforce (Office for National Statistics 2020) and these workers were compensated under the business loan and grant schemes that we discuss later in this paper. The allor-nothing nature of the UK scheme also contrasted sharply with the considerably more closely monitored German scheme. The gross sums spent in the UK wage schemes were therefore higher than they needed to be and the collapse in output was likely also higher because a company was either operating at $100 \%$ regardless of the actual orders, and therefore paid full wages but lost a part of the revenue as a result of lower output, or closed entirely, which meant that its contribution to GDP fell to zero.

Somewhat paradoxically, the "rigid" labor market in Germany, with its highly regulated dismissal procedures, proved a strong starting basis for companies that decided to shift production to what were seen as "essential products," usually associated with the health sector. A structured comparison between two similar companies in both countries that redesigned their products underscores the point. In late April 2020, the manufacturing company Viessmann started producing portable ventilators, mobile care units, and face masks instead of their usual heating systems. They did so in close cooperation with doctors from local hospitals and academic experts from the prestigious local technical university RWTH Aachen - a form of cooperation that is far from unusual in Germany (Viessmann 2020). ${ }^{3}$ In an almost perfect parallel case study in the UK, such a conversion proved much more difficult: Many observers rightly lauded Dyson, the manufacturer of high-end vacuum cleaners, for being able to design a functioning ventilator in ten days (Pooler and Hollinger 2020; Foster and Pooler 2020), but in their idolatry they ignored that the actual retooling of the plants and the concomitant conversion of the workforce was considerably less successful (surprisingly, the Daily Mail, usually among the more nationalist voices in the UK, was the only one to raise this counterpoint; Chadwick 2020). Unable to gain the contract, Dyson ended the project a few weeks and $£ 20$ million later. As this demonstrates, the intrinsic functional flexibility of the German company allowed it to continue to work, while the UK company failed to translate its high-end engineering capabilities into actual production. There are no systematic data on these successful conversions in Germany, but there are plenty of illustrative examples in the German press (Frese 2020; Orth 2020).

Sectoral coverage was quite similar in both cases but, again, with very different effects. Large parts of the manufacturing sector were affected by closures, as were bars, coffee shops, and restaurants. All of these were closed during the UK lockdown, making about 200,000 workers in the hospitality sector technically unemployed (HMRC 2020). ${ }^{4}$ In Germany, the drop in trade resulting from the lockdown meant that over $90 \%$ of businesses in the sector applied for wage subsidies. The reliance of the British economy on services is often seen as the driver of the greater fall in output and higher rise in unemployment. Inasmuch as this refers to low-productivity, low-wage service companies with intensive face-to-face contacts, such as bars, restaurants, hairdressers, and personal beauty care, this seems correct (although in both countries these businesses were equally affected by forced closures). But in other service sectors, usually associated with higher valueadded activities such as consulting, finance, and law, distancing proved less of a problem - definitely less than in manufacturing, which requires physical presence of both worker and machinery, especially in the sophisticated high value-added manufacturing sector for which Germany is internationally famous. All other things equal, manufacturing would thus have been among the worst hit sectors in this pandemic, and Germany should have been on its knees very quickly. However, because of the intrinsic functional flexibility (Piore 1986) of the German manufacturing sector, what should have been a catastrophe turned into a relative success, while Britain's high employment numbers in low value-added sectors that were unable to trade significantly increased unemployment once COVID-19 hit.

Mass redundancies provide an area with highly consequential differences in the institutional background of labor market policies. In the UK, the layoff procedure is basically governed by individual labor law. An employer announces redundancies and unless there are collectively negotiated deviations, the law stipulates how much notice every worker needs to be given, and what the redundancy package entails. The arrangement is far from generous, especially by continental standards: One week of notice pay if employed for less than two years, and an extra week of notice pay for every year with the same employer. The flexible labor market in the country leaves the initiative, with very few constraints, entirely to employers. Since many UK companies, especially small- and medium-sized companies (SMEs), often live hand to mouth with very low savings, the path of redundancies is usually the fastest "tried and tested" way to cut costs; larger companies do so 
because of shareholder pressures. The overall effect is that significant drops in economic activity are almost immediately reflected in rising redundancies and unemployment. Ultimately then, employees and the welfare state in the UK have paid the cost of the economic downturn associated with COVID-19.

Arrangements in Germany follow a fundamentally different logic. Collective redundancies are always subject to wide consultation with the works council, collective negotiations with trade unions, or some form of bargaining with other workforce representatives. Importantly, the costs of the social plan that follows these negotiations are in principle borne by the company, and because of the power of the unions and works councils inside the companies they usually entail quite generous redundancy packages. Coupled with the possibility of applying to Kurzarbeit schemes, the calculation for individual employers is almost the exact opposite of their UK counterparts: Instead of unilaterally deciding on mass redundancies, German employers prefer the wage subsidy schemes. These allow them to retain their skilled workforce at a reduced cost (which, therefore, also entices worker and employer to jointly invest in skills; Hassel 2007).

Making sense of the differences in wage subsidy programs. The most intriguing conclusion of this detailed analysis of different aspects of the ostensibly very similar wage subsidy schemes is that after only a few months of implementation, their effects appeared to diverge significantly. To a large extent, these different effects are a function of the institutional complementarities at the heart of our argument here. The interaction of Germany's Kurzarbeit scheme with its strong works councils and unions elevated the scheme from a short-term job-retention program to one fostering long-term employment whereas British workers always had at least one foot in unemployment.

First, the absence of strict and closely monitored working time patterns in the highly flexible UK labor market has made part-time wage subsidy schemes very difficult to organize. Preventing fraud without incurring exorbitant monitoring costs forced companies either to work or close full time. In Germany, in contrast, the rigid working-time patterns across the economy, which are policed by works councils and trade unions, have not led to a total collapse of the economy due to insufficient flexibility. They have actually been the foundation of the successful Kurzarbeit scheme, which have allowed companies to produce on a part-time basis without increased costs for them and wage losses for workers.

The nature and organization of skills is another area where superficially small differences had big consequences. The intrinsic functional flexibility of highly skilled German workers enabled the rapid and successful adjustment of companies in response to collapsing product markets and the emergence of new COVID-related demand. In the
UK, in contrast, top-level product engineers redesigned products to meet the same goals in a matter of days; yet, reorganizing the company and the workforce to actually start making the new products proved too steep a hill.

Similarly, the different organization of mass layoffs has meant that German employers think again when production falls, lest they face social conflict, a high redundancy bill, and the loss of valuable skills. British employers faced with the end of the Job Retention Scheme in late summer 2020 were subject to almost diametrically opposed incentives and laid off large numbers of workers in an attempt to balance the books.

In late September 2020, faced with a second COVID19 wave and rapidly rising unemployment as a result of renewed lockdowns, UK Chancellor Sunak was therefore forced to introduce a new version of the furlough scheme (the existing one was scheduled to run out in its current form at the end of October 2020). It is copied directly from and is even closer to the German Kurzarbeit program than the original furlough scheme, introducing a part-time wage subsidy for companies that planned to retain workers but were uncertain about working at $100 \%$ of capacity. The government also picked up a maximum of $22 \%$ of the salary (with a monthly cap of about $£ 700$ /month-about $\$ 1,000$ ), down from $80 \%$ initially and $60 \%$ in the final stages of its predecessor, with a monthly maximum of $£ 2,500$. Employees were supposed to forego one-third of their wages - with $30 \%$ of full-time work as the floor where the scheme kicked in; and employers contributed the remainder, about $55 \%$ of monthly wages, up from about $20 \%$ under the old scheme. The Treasury projected savings of about two-thirds of the initial scheme, or several billions of pounds sterling per month, by shifting much of the financial burden onto employers.

Since the new wage-subsidy scheme now looked almost exactly like the German one (but with a high relative contribution by employers), we can even better isolate those elements that are necessary to make such a scheme work. Three crucial elements at the basis of the German success stand out. First, the German setup combines juicy visible carrots with heavy sticks in the background. Employers have invested significantly in the skills of their workforce, which makes them reluctant to see those go. Kurzarbeit is, in that sense, as much a job retention scheme as a program to retain and develop skills. The stick is provided by the highly institutionalized and expensive mass lay-off procedure discussed earlier. Incentives for German employers are therefore heavily skewed in favor of participation in the wage scheme. Secondly, there is the highly organized form of micro-corporatism in German companies under which workers and employers jointly negotiate and organize the actual operation of the scheme, even though the employer applies to the Ministry of Labor for funding. And finally, a similar point can be made for the macro-level "embeddedness" of these measures: in 
many CMEs with corporatist national labor market institutions discussing such schemes in response to a crisis is standard practice, while in LMEs the introduction of such schemes is the result of ad hoc, topical negotiations during the crisis, not before, and crucially dependent on government initiatives. Training has an inherent long-time horizon, both for the initial investment and for the "amortization." If it is to entice German employers to commit to (re)training programs in the context of Kurzarbeit, therefore, the German government is aware that it needs to provide an open-ended scheme, and not one containing consecutive cliff-edges, like in the UK.

Combined, these three elements-the incentives, the micro-corporatist, and the macro-corporatist structuresare prominent in Germany (and many other North-West European political economies), but almost entirely absent from the UK scheme. Skill development remains the Achilles' heel of the British training system, while employers can hire and fire more or less at will; company industrial relations remain adversarial and mired in mutual distrust; and the encouraging signs of agreement between social partners at the start of the crisis (Coulter 2020) may well turn out to be a simple temporary alignment of short-term interests once the shift in the financial burden is absorbed. In short, robust union presence and embedded social dialogue have proven to be deeply complementary to job-retention schemes, generating a flexible yet stable and long-term system of employment guarantee in Germany.

The next section undertakes a parallel analysis of the business loan and grant schemes, which were introduced for similar reasons to the wage schemes - the inability to trade - in both countries in very similar ways. Like our analysis of the wage schemes, the finance scheme suggests that something that looked quite similar at the outset ended up working in very different ways in both countries, and to large extent this had to do with the position of the financial system in the political economies of the UK and Germany.

\section{The Institutional Underpinnings of Business Emergency Loans}

Once the extent of the COVID-crisis had become clear, governments throughout Europe were quick to prepare their fiscal arsenal in order to safeguard domestic business from an unprecedented downturn. In Britain and Germany, governments turned to a complex mix of tax cuts and deferrals, employment and welfare support, and direct grants and business loan support schemes. Here we analyze the implementation and effects of these business support schemes. In the first six months of the crisis (between March and August 2020), the UK extended direct loans or guarantees of about $£ 53$ billion ( $\$ 72$ billion) while the figure in Germany stands at around $€ 54$ billion ( $\$ 66$ billion). What is more, these programs have resembled each other in terms of substance as well. Despite these similarities, however, there have been substantial differences in their implementation, target groups, and, as a result, their effectiveness.

Comparing business support schemes. At the heart of British and German efforts lay fundamentally similar business support policies that offered cheap and easily accessible credit to help firms weather the COVID crisis. In midMarch 2020, the German government announced its widely targeted KfW-Unternehmerkredit (company credit supplied and underwritten by the public investment bank $K f W$ ) while the British Treasury launched two separate schemes with the Coronavirus Business Interruption Loan Scheme (CBILS) for SMEs and the COVID Corporate Finance Facility (CCFF) for large companies. Both countries then complemented these initial policies with another wave of initiatives targeting firms that struggled to access credit under the first round of schemes. The UK introduced the Coronavirus Large Business Interruption Loan Scheme (CLBILS), the Future Fund and its Bounce Back Loans, while Germany initiated the KfW-Schnellkredit (“instant loan" program).

The British and German flagship policies, CBILS and KfW-Unternehmerkredit respectively, resembled each other in many ways. Both schemes allowed businesses access to cheap credit by providing banks with substantial government guarantees while granting generous repayment periods. In Germany, the government backed $80 \%-90 \%$ of business loans depending on firm size, with a two-year grace period on repayments. The British Treasury, in turn, provided a fixed $80 \%$ guarantee in addition to covering fees and interest payments for the first twelve months. In both cases, the policies were implemented through government-backed investment banks in partnership with local banks. In Germany, the Kreditanstalt für Wiederaufbau (KfW-literally "Credit Agency for Reconstruction") assumed its long-standing role as provider and guarantor of special loans. These were processed by the house banks (or Hausbanken in German; henceforth, we will use this term to designate all banks that have long institutionalized relations with firms of all sizes) of the applicants. In much the same vein, the British Business Bank (BBB) administered the government's business lending programs. However, rather than accepting applications from any UK-based bank, the BBB organized a pool of accredited lending institutions (initially 40, later expanding to 102) to take part in the scheme.

Despite their many similarities, there were some clear differences between the CBILS and Unternehmerkredit. Interest rates, for example, were set at a fixed rate in Germany while British banks operating under the Coronavirus Business Loan Interruption Scheme were free to set their own rates. Moreover, the Unternehmerkredit scheme allowed firms of any size to participate and offered loans of up to $€ 100$ million. CBILS, by contrast, was specifically 
aimed at businesses with a maximum turnover of $£ 45$ million, with loans of up to $£ 5$ million only. After initial pushback, the British Treasury balanced its SME-focused CBILS by organizing the Covid Corporate Finance Facility (CCFF) in cooperation with the Bank of England (BoE). CCFF targeted large investment grade corporations by having the BoE directly buy up commercial paper issued by corporations. The minimum issuance in this scheme stood at $£ 1$ million with a maximum maturity of one year.

In addition to these initial programs, both the German and the British government further bolstered their fiscal support for businesses with new schemes during the months that followed. Already in early April 2020, Germany introduced the Schnellkredit catered to smaller and younger companies that struggled to access credit under the Unternehmerkredit. In contrast to the latter, this new program offered lines of credit up to $€ 800,000$ at a fixed $3 \%$ interest rate with a full $100 \%$ guarantee from the $K f W$. The UK, similarly, introduced the so-called Bounce Back Loans (BBL) targeting micro-firms with loans between $£ 2,000$ and $£ 50,000$ at $2.5 \%$ interest and a $100 \%$ guarantee to address the problem of mounting credit hold-ups for small firms. The British government supplemented this scheme with the announcement of the Future Fund and Coronavirus Large Business Interruption Loan Scheme (CLBILS). The Future Fund specifically aimed at providing direct liquidity to startups which could not access existing schemes stipulating that businesses needed to show profitability. The Coronavirus Large Business Interruption Loan Scheme, on the other hand, expanded CBILS to include firms with a turnover above $£ 45$ million as it soon became clear that a substantial share of businesses could neither access CBILS nor CCFF.

The effects of loan schemes in Germany and the UK. While these financial support packages were tailored to help certain groups of businesses, they also left others out of the reckoning. This is particularly the case for the UK where the initial policy response along the lines of CBILS and CCFF explicitly excluded two types of firms. On the one hand, businesses that were not (yet) profitable remained outside the schemes' purview, as the Treasury was apprehensive about artificially propping up already struggling firms (Lynch 2020; Milne 2020). Many profitable medium and large enterprises, on the other hand, had nowhere to turn to either, because CBILS support capped annual turnover of applying firms at $£ 45 \mathrm{~m}$ while CCFF targeted the very largest companies in the UK, few of which would have struggled to access funding in the first place. While the introduction of the Coronavirus Large Business Interruption Loan Scheme in April 2020 did appease this previously neglected group, the Bounce Back Loans clearly signaled that the government's priorities lay with the two extremes in the size distribution - the very big corporations and the very small shops on the local high street.
This outcome contrasts sharply with what happened in Germany. First of all, German stipulations of pre-COVID profitability were more lenient, only making it a hard condition for loans exceeding $€ 800,000$. The Unternehmerkredit was also a more broadly oriented instrument. Not only did it not make any stipulations regarding firm size, but the wide range of available loans made it an attractive proposition to businesses of all sizes. Most importantly, the close ties between firms and their Hausbank, the financial institution that they would normally do business with and which had detailed knowledge of the company's credit situation, significantly simplified the emergency loan application process.

Yet some firms in Germany initially struggled to access the liquidity necessary to stay afloat. After the introduction of the Unternehmerkredit, SMEs and their representative associations complained that they were facing insurmountable obstacles trying to convince banks to guarantee $10 \%$ or $20 \%$ of the share of loans that were not covered by the $K f W$ (Welp and Zdrzalek 2020). This was especially the case for those firms that had made significant investments in the runup to the COVID crisis and had been temporarily in the red as a result, as well as for those whose business models were most affected by the economic shutdown. In addition, recently established firms were also shut out as businesses that had spent fewer than five years on the market were not eligible. Both these examples demonstrate very clearly that the schemes were organized around the "traditional" links between established, profitable firms and their house banks and that companies falling outside this mold faced significant problems. The government addressed the concerns of the SMEs by introducing the Schnellkredit, providing fully covered loans but capped at $€ 800,000$ per application.

As a result, though very similar on paper, the coverage and operation of the British and German business support programs were each other's almost perfect counterparts. In the UK, those firms that required help most urgently also seemed to struggle most to get it as CBILS proved highly ineffective. In fact, in the first week of implementation only 983 out of 130,000 applications were approved, amounting to a (not so) grand total of only $£ 90$ million in cash disbursements (Pratley 2020). In April 2020, the British Chamber of Commerce (2020) polled that only $13 \%$ of applications had been successful while the remaining were either left unprocessed or denied. Data on SME business lending during March and April 2020 support this conclusion: while lending among large corporations spiked in March, a similar surge for SMEs only emerged at the end of April. ${ }^{5}$ Things improved over time as more banks came online, but only slightly. By mid-August 2020, still more than half of the CBILS loans were rejected, and of the other loan and grant schemes, only the BBLs approached its target with about $80 \%$ of applications approved. Rejection rates remained high for the 
other two schemes as well: $48 \%$ for CLBILS, and 35\% for the Future Fund ${ }^{6}$. Finally, low numbers of total applications indicate not only that many firms were unsuccessful with their applications, but also that many were simply ineligible for the support schemes in the first place. These included businesses exceeding $£ 45$ million in turnover but which were not among the top 100 in turnover.

In Germany, the situation of these medium-sized firms was much more favorable. Supported by their house banks, applications were submitted swiftly and passed on to the $K f W$ where automated assessments guaranteed extremely high acceptance rates. In stark contrast to the UK, however, the smallest firms, especially those with fewer than eleven employees-making up $89 \%$ of all businesses (Statista 2020) —and the self-employed faced an uphill battle. They were excluded from the $K f W$ Schnellkredit and had to apply for emergency grants from their local governments in the Länder instead. Given caps on the size of programs, the bureaucratic cost of applications in many cases far exceeded the utility of the grants available to them and cases of fraud further hampered the efficacy of the support schemes.

Thus, the puzzling result when comparing the effects of business support schemes in the UK and Germany is that the very companies that fell through the cracks in the UK experienced the strongest support in Germany and vice versa. While SMEs from Germany's famed Mittelstand faced only very limited challenges in applying for emergency aid, the traditional high street shop was left out.

The institutional foundations of diversity in the business support schemes. Why were the outcomes of these two generally similar emergency loan programs in the UK and Germany so different? The answer lies in the organization of the domestic financial systems. In the UK, two fundamental problems effectively shut out medium-sized businesses: an information problem and an incentive problem. Private banks that wanted to participate in the emergency loan programs had to apply and register with the British Business Bank. Given unclear risk and cost structures, the number of banks participating in the schemes was limited, which created a bottleneck from the outset. Many applicants that were in dire need of financial support therefore could not work with their usual credit institution, while those lenders that had most expertise in working with SMEs were unable to act as facilitators. Many SMEs were left in the uncomfortable position of having to convince anonymous lenders of their creditworthiness as a result. For CBILS in particular, these credit assessments were automated through centralized application platforms that were plagued by glitches and resulted in very high denial rates. In addition, the British Business Bank approved lenders on a rolling basis, which resulted in swift approvals for the UKs largest private institutions, principally Barclays, HSBC, NatWest, and Lloyds. These four banks together ended up dispensing $89 \%$ of the funds under the Coronavirus Business Interruption Loan Scheme. While providing the government with scale and capacity, these banks also relied most on standardized application processes with the least granular information on SMEs.

These information problems were exacerbated by gravely misaligned incentives, which put private banks in a difficult position. As the government did not set fixed interest rates for the loan programs, the costs to banks of emergency loans were mounting and, in many instances, eligible applicants were nudged into regular loan products which were more profitable to private lenders. Moreover, at the outset of CBILS, much uncertainty prevailed over the right of banks to demand collateral in the form of personal assets from applicants. Many applicants, particularly smaller firms, thus were priced out of loans during the early weeks of the program. These problems were effectively tackled only when the government introduced the Bounce Back Loans scheme that guaranteed 100\% of the loans at a fixed $2.5 \%$ interest rate while expanding eligibility criteria, making it virtually impossible for banks to demand collateral. Unsurprisingly, data indicate that the Bounce Back Loans program has by far been the most popular support scheme during the first wave: by midAugust 2020, BBL had lent over $£ 35$ billion $(\$ 47.5$ billion) compared to $£ 13.5$ billion ( $\$ 18.4$ billion) under CBILS. The "Malthusian" high-street shops received most political attention and support after the initial failures of the program, and policy emphasized protecting unemployment statistics that were certain to explode when support schemes turned out to be ineffective in stabilizing these very small and micro businesses.

In Germany, the institutional preconditions of the financial system alleviated both the information and incentive problems that troubled the UK schemes. Most importantly, banks of all sorts and sizes were in principle eligible and motivated to participate as facilitators in the support schemes. At the micro-level, relational lending constitutes a deeply institutionalized element of Germany's post-war financial system (Zysman 1983; Deeg 1998, 2010; Hall and Soskice 2001). Small- and mediumsized businesses in particular have maintained close personal relationships to their Hausbanken, which do not only hold significant knowledge about their clients' credit history, but also about their business models, market position, and long-term strategies. ${ }^{8}$ At the meso-level, the publicly guaranteed $K f W$ implemented the government's support schemes. Established in 1948, KfW s founding purpose laid in supporting post-war reconstruction efforts by facilitating and distributing funds from the Marshall Plan. Over the course of its seventy-year-long history, the $K f W$ has specialized in distributing its AAArated government-backed capital by providing affordable loans to domestic and international clients, often facilitated through local Hausbanken. 
When COVID-19 struck, this allowed the German government to fall back on a deeply institutionalized system of bank-to-business and bank-to-bank links that could easily be deployed as a public utility. Public savings banks and cooperatives shouldered over two-thirds of the volume of Unternehmerkredit and Schnellkredit loans while holding a total market share of only around 30\%. Furthermore, banks were actively incentivized to participate in the loan programs by being promised an interest margin of $0.2 \%$ and a one-off payment of $€ 1,000(\$ 1,200)$ per application while taking on no or very low credit risks (Dohms 2020; Osman, Atzler, and Holtermann 2020). The combination of these conditions resulted in extremely high acceptance rates of $99.95 \%$ of all loan applications that passed the initial assessment stage at the Hausbank level. Compared to the informational hold-ups experienced in the UK, this swift exploitation of the infrastructural position of the Hausbanken to distribute loans shows that the public utility function of Germany's secondary banking sector remains a central aspect of the German political economy.

Yet all that glitters is not gold, even in Germany. Critics from the ranks of Germany's opposition parties, most notably Green party representatives, have voiced increasing concerns about Germany's emergency loans program. They suggest that exceptionally high acceptance rates indicate a lack of credit risk assessment which may provide the basis for the rise of so-called "zombie firms," that is, failed businesses on life support (Chazan and Arnold 2020).

While it is too early to evaluate this risk, arguably more worrisome than those businesses receiving help that they do not deserve, are those that need funding but are unable to access it. As with every deeply institutionalized system, it seems to work well for insiders but discriminates against those who lack access. In contrast to the UK, the very smallest firms in Germany have struggled to get the help they needed. As discussed earlier, businesses with fewer than eleven employees, including the self-employed, were a priori excluded from $K f W$ loan programs. These could not rely on the infrastructural support and reputation of a Hausbank, and when lacking relevant collateral, they had only the state financial authorities to turn to. Many of the smallest businesses therefore complained that financial aid was not provided fast enough and that they felt abandoned during the process (FinCompare 2020). Whereas British policies seemed to protect its smallest and largest firms but not its SMEs, the German schemes ended up protecting the latter, the heart of the country's economic model, but did so at the expense of the former.

In addition, the distribution of emergency grants by local authorities in Germany to those businesses ineligible for bank loans was significantly hampered by swiftly rising numbers of fraudulent applications. Federal authorities investigated a total of 20,000 individual cases, which led some Länder to temporarily suspend their grant schemes altogether (Ruhr Nachrichten 2020). In stark contrast, there are little to none known cases of fraud related to the emergency loan programs facilitated by $K f W$ and the Hausbanken. Notably, and yet again, the picture in the UK is an almost perfect inverse of the situation in Germany. Here, authorities soon realized that the relatively unregulated Bounce Back Loans in particular were ripe for "being abused and defrauded on an industrial scale," in the words of an anonymous senior banker cited in the Financial Times (Thomas and Morris 2020). Estimates from December 2020 suggest that more than half of the $£ 43$ billion lent under the BBL program could be lost with fraud being a major source of financial damage (UK Parliament 2020).

Germany's almost diametrically opposite experiences regarding efficacy and fraud in the loan schemes are, again, best understood from the perspective of complementarities between different elements in the institutional framework and policies. The UK faced immense challenges to distribute emergency loans in an orderly fashion because of a lack of mutual articulation of different elements in its financial system. Germany, in turn, could rely on the formal and informal existing ties between local Hausbanken and recipient firms during the vetting process. However, when Germany could not fall back on its deeply institutionalized financial infrastructure, the country faced very similar problems with fraud. When local governments were forced to distribute emergency grants directly, they became an easy target for professional fraudsters. Only where coordinated institutional resources meshed to create beneficial complementarities could frictionless financial support be guaranteed.

In sum, despite initiating similar business loan programs, the effects of the financial interventions in Germany and the UK could hardly have been more different. Not only did the British programs suffer from comparative inefficiencies during their first weeks, but the Treasury's policies also targeted a different set of firms than their German counterparts. The German programs sought to stabilize the country's industrial base of Mittelstand firms while the British government targeted very large and very small firms at either extreme of the scale. This puzzling gap between the similarity of the formulation of these policies and their diverging outcomes is a function of variation in the supply-side institutions in Germany and the UK. In the former, the crisis programs are an extension of deeply institutionalized relations between firms, banks, and the state. These institutional legacies allowed German banks and the $K f W$ to overcome information asymmetries regarding firms' solvency. The German banking sector thus could do what it has done so well for decades - act as the key cog in business-state relations to facilitate industrial development. Instead of ending up in the dustbin of history with the large commercial banks (Hardie et al. 
2013), relationship banking, the model at the core of the German system, showed its strengths during the COVID19 crisis.

In the UK, on the other hand, financial support for businesses has primarily been a countercyclical tool. In its essence, the Coronavirus Business Interruption Loan Scheme is a rerun of the 2009 "Enterprise Finance Guarantee" designed to stabilize the economy during the Great Financial Crisis. Whereas the German government explicitly decided to work through the $K f W$, the UK had no choice but to engage with commercial banks. Lacking the institutional resources available to Germany, the Treasury ended up introducing Bounce Back Loans to overcome the limitations of CBILS. As a result, Bounce Back Loans became the most important funding line for British business; in contrast, the comparable Schnellkredit in Germany has been a residual measure at best.

\section{Conclusion: Institutions and Economic Policies}

Crises such as COVID-19 offer a window into the key mechanisms that underpin political-economic systems: What is often disguised under a layer of normality in other periods forces itself to the forefront in such moments of high tension. A detailed analysis of the responses to the economic fallout of the health crisis by governments in two very different varieties of capitalism, the CME Germany, and the LME UK, at first glance seems to suggest that both converged in their reactions. A similar shock in different systems led to essentially the same economic policy responses, at the same time, carried by different government coalitions but with similar support from business and labor. A more nuanced analysis of the economic policies as part of a set of mutually reinforcing institutional arrangements- "complementarities" in the VoC vocabulary-suggests a very different conclusion, however. Both the furlough and the business support schemes were implemented in very different ways in both places and with diverging effects. In combination with other elements in the institutional setup, furlough schemes minimized unemployment but also, and importantly, preserved high, specific skills in Germany while mainly acting as a short-term buffer to unemployment shocks in the UK. Small and medium-sized enterprises did well out of the loan schemes in Germany but not in the UK, while the very largest and smallest companies benefited in the UK but considerably less so in Germany. Wherever we look, policies that appeared to be part of the same broad family of economic responses ended up producing very different effects - mainly as a result of how they interacted with underlying systems and strategies on the supply side of the economy. If this is true for policy responses to COVID-19 in Germany and the UK, it is probably also the case in other domains and other countries. Examining how policy is shaped by institutional complementarities, especially when importing elements without the full institutional infrastructure, should help us understand at which points policies fail because of systemic reasons, and what minimum systemic adjustment is necessary for them to work (see Levy 1999; Jacoby 2000 for early discussions of these insights).

This has significant implications for policymaking. If the effects of policies are as dependent on underlying, often deeply rooted, institutions as we suggest here, simply introducing policy elements developed elsewhere becomes very difficult, if not impossible. Their effectiveness depends to a large extent on the existence of institutions that may be hard to construct or manipulate. Policies need to be compatible with these underlying institutional frameworks and the incentives they produce for actors operating within them, else they run the risk of failure, or worse, make a bad situation worse. This is not only a call for care with policy innovation, but also advocates considering the unintended (but not necessarily unknowable) interactions between different elements in a political economy. Since these issues are not context-specific but more general problems of policymaking, this idea is likely to travel outside the UK and Germany to the further corners of the capitalist world, and perhaps even beyond.

Our examination of economic policy responses to COVID-19 also suggests a correction to a very specific recent debate in the comparative political economy frameworks that we use to understand the world. Our attention to institutional complementarities and the way they shape policy outcomes suggests quite strongly that divergence in capitalism can play out in sometimes unexpected ways. We discovered that when examining the effects of differences in the organization of the labor market-but these differences had always been quite significant and, therefore, perhaps not particularly surprising.

More surprising, perhaps, these complementarities were also extremely important in the business loan and grant schemes, where our analysis intersects with a vibrant debate on the reach of global financialization and the convergence of national financial systems (Van der Zwan 2014). There is no doubt that the German banking system-once the hallmark of Zysman's (1983) "bankled" system - has become more "market-led" as a result of increased disintermediation and exposure to global financial markets (Hardie et al. 2013). Even some of the more conservative savings banks have not been immune to the lure of new financial products and services (Schwan 2020; Cassell 2021). But the rise of market-based banking should not be interpreted prematurely as the sure-fire demise of the German relational banking model nor as the end of meaningful typologies of financial systems. Instead, existing institutional complementarities tend to be quite durable and as a result, both market-based and relational styles of banking can coexist under the roof of one coherent type of capitalism. 
In particular, the swift exploitation of the infrastructural position of the Hausbanken to distribute loans demonstrates that the public utility function of Germany's secondary banking sector remains as central to the system as ever. While large commercial banks did indeed cut ties to domestic capital markets and turned to Wall Street and international investment banking, most of the smaller local banks remained true to their traditional role of providers of industrial credit and served as the gatekeepers to business support schemes during the crisis. Deeg (2009; 2014) argues that this process of institutional bifurcation has effectively protected large parts of the German financial system from the pressures of international markets, rather than absorb them into the global financialization vortex. Our findings suggest that most banks in coordinated market economies still have the capacity to serve as active intermediaries and to engage not mainly or exclusively with other financial actors, but also-and crucially so-with the real economy. Put differently, more than simply retaining its institutional features, this system is still very much alive in a functional sense as well. In sum, a large part of the German financial system is, and remains, bank-led, and precisely that part was at the core of the response to COVID-19.

Financial systems and labor markets in Germany and Britain remain very different, and when mobilized in a crisis like the one that COVID-19 has provoked, these differences may be matters of-literally_life and death. A perspective that builds on institutional complementarities develops explanations for success and failure that go well beyond the quality of policies or policymakers and forces us to think more systematically about the way institutional frameworks actively shape outcomes. We suggest that even though they will never be the whole story, they are an important and almost certainly a necessary element in understanding differences across capitalist systems - even when everything else suggests that we are or should be witnessing deep, systemic convergence.

\section{Acknowledgements}

Many thanks to Nick Barr, Steve Coulter, Saul Estrin, Angela Garcia-Calvo, Kira Gartzou-Katsouyanni, Michel Goyer, Abby Innes, Andrew McNeil, and Waltraud Schelkle for helpful comments on an earlier version. We are also grateful to the reviewers for Perspectives on Politics and its editor for their help. Any omissions and mistakes are entirely our responsibility. Comments welcome.

\section{Notes}

1 See Wired "The UK's coronavirus furlough scheme, explained by experts," July 29, 2020 (https://www. wired.co.uk/article/uk-furlough-scheme-job-protec tion) for a concise and transparent description of the UK scheme. HMRC 2020 gives statistical details on the schemes. A description in English of the German scheme can be found in Bloomberg "Explaining Kurzarbeit, or Saving Jobs the German Way.” (https:// www.bloomberg.com/news/articles/2020-04-03/howgermany-pays-workers-when-their-work-driesup-quicktake).

2 By early 2021, the wage scheme had been stopped and restarted twice.

3 In addition to Viessmann's press release, see Handelsblatt "Heizgerätehersteller Viessmann baut nun auch Beatmungsgeräte," April 20, 2020 (https://www. handelsblatt.com/unternehmen/mittelstand/familie nunternehmer/familienunternehmen-gegen-coronaheizgeraetehersteller-viessmann-baut-nun-auchbeatmungsgeraete/25752624.html?ticket=ST2272808-aybJrtDWpjwSwhpbJ03W-ap2).

4 See data from the Office for National Statistics 2020, not seasonally adjusted.

5 See the Bank of England, Monetary financial institutions' loans to UK small and medium-sized enterprise (https://www.bankofengland.co.uk/statistics/details/ further-details-about-monetary-financial-institutionsloans-to-non-financial-businesses-data).

6 For day-by-day data, see https://www.gov.uk/govern ment/collections/hm-treasury-coronavirus-covid-19business-loan-scheme-statistics\#Bounce-Back-LoanScheme.

7 Note that business grant schemes are independent from the government-backed loan schemes in substance and practice. The former concerns direct transfers from the government to firms and does not rely on banks acting as intermediaries. The higher degree of anonymity might serve as an explanation why Germany saw relatively more instances of fraud in the grant scheme than in the loan programs; see Financial Times "Germany cracks down on coronavirus aid fraud," April 19, 2020 (https://www.ft.com/content/c2123b10-2fa5-4fe79422-44de8541f527).

8 One might reasonably suspect that the dependence on the close ties between Hausbanken and firms invited fraud. Hausbanken could be much too positively predisposed towards ailing SMEs to be trustworthy facilitators. But there are currently no registered cases of fraud in the business loan programs. Given the critical attitude of the opposition parties-notably the Greens and the liberal FDP - to the business loan schemes, such cases would quickly have surfaced if they existed. The main reason for this absence of fraud seems related to the residual $10 \%-20 \%$ that banks have to cover from their own funds - at least for the Unternehmerkredit scheme- the grave reputational costs to banks, and ultimately the severe penalties, including up to five years in jail.

9 A term famously coined by Germany's finance minister Olaf Scholz (SPD). 


\section{References}

British Chamber of Commerce. 2020. "BCC Coronavirus Business Impact Tracker: Loan Schemes Still Slow to Help Many Cash-Strapped Firms_-but Furlough Scheme Preventing Redundancies." British Chamber of Commerce, April 29. (https://www.britishchambers. org.uk/news/2020/04/bcc-coronavirus-businessimpact-tracker-loan-schemes-still-slow-to-help-manycash-strapped-firms-but-furlough-scheme-preventingredundancies).

Cassell, Mark K. 2021. Banking on the State: The Political Economy of Public Savings Banks. Newcastle: Agenda Publishing.

Cavallino, Paolo, and Fiorella De Fiore. 2020. "Central

Banks' Response to COVID-19 in Advanced

Economies.” BIS Bulletin No. 21. Bale: Bank for International Settlements.

Chadwick, Jonathan. 2020. "Could Dyson and Rolls Royce REALLY Make Ventilators to Treat Coronavirus Victims? Experts Warn Converting Production Lines to Build Life-Saving Equipment Will Take 'Many Months'." Daily Mail Online, March 16. (https:// www.dailymail.co.uk/sciencetech/article-8117847/ Dyson-JCB-Rolls-Royce-face-problems-makingventilators-experts-warn.html).

Chazan, Guy, and Martin Arnold. 2020. "Germany Haunted by Spectre of Zombie Companies." Financial Times, August 20. (https://www.ft.com/ content/5d5d1bc1-61a3-46a9-915c-1a1e6f2e5fd2? share'Type=nongift).

Coulter, Steve. 2020. "All in it Together? The Unlikely Rebirth of Covid Corporatism." The Political Quarterly 91(3): 534-541.

Criado-Perez, Caroline. 2019. "The Deadly Truth about a World Built for Men-from Stab Vests to Car Crashes." The Guardian, February 23. (https:// www.theguardian.com/lifeandstyle/2019/feb/23/ truth-world-built-for-men-car-crashes).

Deeg, Richard. 1998. "What Makes German Banks Different." Small Business Economics 10(2): 93-101 _ 2009. "The Rise of Internal Capitalist Diversity? Changing Patterns of Finance and Corporate Governance in Europe." Economy and Society 38(4): $552-79$.

- 2010. "Industry and Finance in Germany since Unification." German Politics and Society 28(2): 11629.

. 2014. "Financialization and Institutional Change in Capitalisms: A Comparison of the United States and Germany." Journal of Comparative Economic Studies 9 (1): 47-68.

Department of Health \& Social Care. 2020. Coronavirus Action Plan: A Guide to What You Can Expect across the UK. Retrieved January 15, 2021 (https:// assets.publishing.service.gov.uk/government/uploads/ system/uploads/attachment_data/file/869827/ Coronavirus_action_plan___a_guide_to_ what_you_can_expect_across_the_UK.pdf).

Die Rheinlandpfalz. 2020. "Corona-Virus: Bundesregierung hält Risiko für Deutschland sehr gering." Die Rheinlandpfalz, January 27. (https:// www.rheinpfalz.de/panorama_artikel,-corona-virusbundesregierung-hält-risiko-für-deutschland-sehrgering-_arid, 1579340.html).

Dohms, Heinz-Roger. 2020. "Banken erhalten je KfWSchnellkredit $1000 €$ plus 0,2\% p.a." finanz-szene.de, April 13. (https://finanz-szene.de/banking/bankenerhalten-bis-zu-2600-euro-je-kfw-schnellkredit/).

Economist. 2020. "Europe's Habit of Propping Up Firms May Outlast the Pandemic.” The Economist, May 28. (https://www.economist.com/europe/2020/05/28/ europes-habit-of-propping-up-firms-may-outlast-thepandemic).

FinCompare. 2020. "Zu wenig Hilfe für den Mittelstand.” FinCompare, July 31. (https:// www.barkowconsulting.com/wp-content/ uploads/2020/08/200811-FinCompare-Studie_Die-Corona-Hilfen-kommen-nicht-im-Mittelstandan-2.pdf).

Foster, Peter, and Michael Pooler. 2020. "Muddled Thinking Punctures Plan for British Ventilator." Financial Times, April 17. (https://www.ft.com/ content/5f393d77-8e5b-4a85-b647-416efbc575ec).

Frese, Alfons. 2020. "An diesen Stellen hakt die deutsche Schutzmasken-Produktion." Der Tagesspiegel, April 4. (https://www.tagesspiegel.de/wirtschaft/schutz-vordem-coronavirus-an-diesen-stellen-hakt-die-deutscheschutzmasken-produktion/25714126.html).

Hall, Peter A., and David Soskice. 2001. Varieties of Capitalism: The Institutional Foundations of Comparative Advantage. Oxford: Oxford University Press.

Hardie, Iain, David Howarth, Sylvia Maxfield, and Amy Verdun. 2013. "Banks and the False Dichotomy in the Comparative Political Economy of Finance." World Politics 65(4): 691-728.

Hassel, Anke. 2007. "What Does Business Want? Labour Market Reforms in CMEs and Its Problems." In Beyond Varieties of Capitalism: Conflict, Contradictions, Complementarities in the European Economy, ed. Bob Hancké, Martin Rhodes, and Mark Thatcher, 253-277. Oxford: Oxford University Press.

HMRC. 2020. "HMRC Coronavirus (COVID-19) Statistics.” London, UK: Her Majesty's Revenue and Customs. Retrieved September 21, 2020 (https:// www.gov.uk/government/collections/hmrccoronavirus-covid-19-statistics).

Howell, Chris. 2003. "Varieties of Capitalism: And Then There Was One?” Comparative Politics 36(1): 103-24. 
Jacoby, Wade. 2000. Imitation and Politics: Redesigning Modern Germany. Ithaca, NY: Cornell University Press.

Levy, Jonah. 1999. Tocqueville's Revenge: State, Society, and Economy in Contemporary France. Boston, MA: Harvard University Press.

Locke, Richard, and Kathleen Thelen. 1995. "Apples and Oranges Revisited: Contextualized Comparisons and the Study of Comparative Labor Politics." Politics and Society 23(3): 337-67.

Lynch, Russel. 2020. “Germany's 100pc Guarantees Highlights Shortcomings of UK Loan Scheme.” Daily Telegraph, April 8. (https://www.telegraph.co.uk/ business/2020/04/08/germanys-100pc-guaranteesthrow-spotlight-ailing-uk-loan-scheme/).

Martin, Nik. 2020. "Why Germany's Reduced Hours Scheme Won't Work Long Term." Deutsche Welle, May 11. (https://www.dw.com/en/why-germanysreduced-hours-scheme-wont-work-long-term/a53377212).

Milgrom, Paul, and John Roberts. 1992. Economics, Organization and Management. Englewood Cliffs, NJ: Prentice-Hall.

Milne, Oliver. 2020. "Coronavirus-Hit Firms Get 100\% Backing for Loans in Major Government U-turn." Daily Mirror, April 27. (https://www.mirror.co.uk/ news/politics/breaking-coronavirus-hit-firms-10021934344).

Muller, Joann. 2019. "The Gender Gap in Car Safety Leaves Women at Risk." Axios, July 10. (https:// www.axios.com/gender-gap-car-safety-leaves-womenrisk-bb125ad8-cf13-4546-a4d1-21634e450b3c.html).

Office for National Statistics. 2020. "EMP14: Employees and self-employed by industry." Office for National Statistics, August 11. (https://www.ons.gov.uk/ employmentandlabourmarket/peopleinwork/ employmentandemployeetypes/datasets/ employeesandselfemployedbyindustryemp14).

Orth, Martin. 2020. "Flexibel und innovativ in der Krise." Deutschland.de, April 8. (https://www.deutschland.de/ de/topic/wirtschaft/corona-pandemie-deutscheunternehmen-stellen-produktion-um).

Osman, Yasmin, Elisabeth Atzler, and Felix Holtermann. 2020. "EU gibt grünes Licht für KfW-Schnellkredit." Handelsblatt, April 13. (https://www.handelsblatt.com/ finanzen/banken-versicherungen/coronahilfen-eu-gibtgruenes-licht-fuer-kfw-schnellkredit/25735270.html? ticket=ST-1689716-RWK9hIUGs6RAzbZbzN2Gap4).

Piore, Michael. 1986. "Perspectives on Labor Market Flexibility." Industrial Relations 25(2): 146-66.

Pooler, Michael, and Peggy Hollinger. 2020. "Dyson to Produce 15,000 Ventilators from Scratch 'in Weeks'." Financial Times, March 25. (https://www.ft.com/ content/4cc667f2-6ee2-11ea-89df-41bea055720b).
Pratley, Nils. 2020. “130k Inquiries, 1k Loans: Why UK Government Had to Tweak Help to Small Firms." The Guardian, April 2. (https://www.theguardian.com/ business/2020/apr/02/130k-inquiries-1k-loans-whyuk-government-had-to-tweak-help-for-small-firms).

Reuters. 2020. "Coronavirus Risk to British Public Remains Low: Health Minister." Reuters. January 24. (https://www.reuters.com/article/us-china-th-britainhancock/coronavirus-risk-to-british-public-remainslow-health-minister-idUSKBN1ZN1R9).

Ruhr Nachrichten. 2020. "Razzia nach Betrug mit Corona-Soforthilfe in großem Stil - falsche Anträge in Millionenhöhe." Ruhr Nachrichten, December

2. (https://www.ruhrnachrichten.de/nachrichten/ razzia-nach-betrug-mit-corona-soforthilfe-in-grossemstil-falsche-antraege-in-millionenhoehe1580070.html).

Sampson, Thomas. 2020. "A No-Deal Brexit May Still Be More Costly Than COVID-19.” London, UK: LSE Brexit Blog. Retrieved September 21, 2020 (https:// blogs.lse.ac.uk/brexit/2020/08/26/a-no-deal-brexitmay-still-be-more-costly-than-covid-19/).

Sandbu, Martin. 2021. "Shock Therapy: How the Pandemic Is Resetting Britain's Whole Free Market Model.” Prospect, January/February 2021. Retrieved January 15, 2021 (https://www.prospectmagazine. co.uk/magazine/pandemic-free-market-model-brexitjobs-economy-europe-martin-sandbu).

Schwan, Michael. 2020. "Weathering the Storm? Financialisation and German Savings Banks." New Political Economy. DOI: 10.1080/13563467.2020. 1782365.

Statista. 2020. "Anzahl der rechtlichen Einheiten in Deutschland nach Beschäftigtengrößenklassen im Jahr 2018." Statista, May 13. (https://de.statista.com/ statistik/daten/studie/1929/umfrage/unternehmennach-beschaeftigtengroessenklassen/\#:-:text= Rechtliche\%20Einheiten\%2F\%20Unternehmen\% 20nach\%20Beschäftigtengrößenklassen $\% 202018 \&$ text $=\mathrm{Im} \% 20 \mathrm{Jahr} \% 202018 \% 20 \mathrm{gab} \% 20 \mathrm{es}$,statistischen \%20Unternehmensregisters\%2F\%20Registerstand\% $3 \mathrm{~A} \% 2030$ ).

Steinmo, Sven, Kathleen Thelen, and Frank Longstreth. 1992. Structuring Politics: Historical Institutionalism in Comparative Analysis. Cambridge: Cambridge University Press.

Thomas, Daniel, and Stephen Morris. 2020. “'A Giant Bonfire of Taxpayers' Money': Fraud and the UK Pandemic Loan Scheme." Financial Times, December 20. (https://www.ft.com/content/41d5fe0a-7b464dd7-96e3-710977dff81c?shareType=nongift).

UK Parliament. 2020. COVID-19: Bounce Back Loan Scheme. Retrieved January 15, 2021 (https:// publications.parliament.uk/pa/cm5801/cmselect/ cmpubacc/687/68703.htm\#_idTextAnchor000\% 
20AND\%20https://www.nao.org.uk/wp-content/ uploads/2020/10/Investigation-into-the-BounceBack-Loan-Scheme-Summary.pdf).

Van der Zwan, Natascha. 2014. "Making Sense of Financialization.” Socio-Economic Review 12: 99-129. Viessmann. 2020. "In the Fight against Corona." Allendorf, Germany: Viessmann GmbH and Co. KG. Retrieved September 19, 2020 (https://

www.viessmann.family/en/newsroom/company/inthe-fight-against-corona).

Vlandas, Tim. 2020. “A Pandemic 'Misery Index': Ranking Countries' Economic and Health Performance during COVID-19." LSE EUROPP Blog. Retrieved January 15, 2021 (https://blogs.lse.ac.uk/ europpblog/2020/12/04/a-pandemic-misery-indexranking-countries-economic-and-health-performanceduring-covid-19/\#comments).
Welp, Cornelius, and Lukas Zdrzalek. 2020. "CoronaKredite: Das 10-Prozent-Problem." Wirtschaftswoche, April 3. (https://www.wiwo.de/my/unternehmen/ banken/hilfe-fuer-unternehmen-corona-kredite-das10-prozent-problem/25711258.html?ticket=ST1256727-ciu0zmaJCznCfvu52Nxa-ap6).

Wood, Steward. 2001. "Business, Government, and Patterns of Labor Market Policy in Britain and the Federal Republic of Germany." In Varieties of Capitalism: The Institutional Foundations of Comparative Analysis, ed. Peter A. Hall and David Soskice, 247-274. Oxford: Oxford University Press.

Zysman, John. 1983. Governments, Markets, and Growth: Financial Systems and Politics of Industrial Change. Ithaca, NY: Cornell University Press. 